\title{
The retina in hypertensive disorders of pregnancy: a study of the prevalence and association with severity of disease in a tertiary referral centre in India
}

\author{
Jasmine C. Sharma ${ }^{1 *}$, Bithi Choudhary ${ }^{2}$, Laxmi Maru ${ }^{3}$, Poonam Mathur ${ }^{3}$
}

\begin{abstract}
${ }^{1}$ Department of Obstetrics and Gynecology, Hindu Rao Hospital and NDMC Medical College, Delhi, India ${ }^{2}$ Department of Ophthalmology, Hindu Rao Hospital and NDMC Medical College, Delhi, India

${ }^{3}$ Department of Obstetrics and Gynecology, MGM MC and MY Hospital, Indore, Madhya Pradesh, India
\end{abstract}

Received: 16 November 2019

Accepted: 10 December 2019

\section{*Correspondence:}

Dr. Jasmine C. Sharma,

E-mail: drjasminechawla@gmail.com

Copyright: $\odot$ the author(s), publisher and licensee Medip Academy. This is an open-access article distributed under the terms of the Creative Commons Attribution Non-Commercial License, which permits unrestricted non-commercial use, distribution, and reproduction in any medium, provided the original work is properly cited.

\begin{abstract}
Background: Hypertensive disorders of pregnancy remains to be a major cause of maternal and fetal morbidity and mortality. The retina offers the unique opportunity to directly observe changes in the vasculature due to preeclampsia. Fundoscopy can be used to prognosticate and assess the severity of disease and offer an optimum time of delivery to improve fetomaternal outcome. There are limited number of studies from northern India assessing the relationship between hypertensive disorders of pregnancy and retinopathy. This study was undertaken to bridge this gap.

Methods: This was an observational cohort study undertaken in a tertiary hospital, 225 patients of preeclampsia coming to the department were identified and a structured proforma used to gather relevant information. All patients underwent fundoscopy and were classified into groups on the basis of fundal grade observed. The groups were compared in terms of clinicodemographic variables. Appropriate statistical tests were applied.

Results: A total $68 \%$ patients had retinal changes of which the most common grade was grade 1 There was a significant rise in the mean systolic and diastolic blood pressure with increasing grade of fundal change. The (p-value 0.001). $65.5 \%$ of patients of preeclampsia without severe features (i.e. mild cases) had no retinopathy. None of these patients had grade 3 or 4 changes. In the patients of preeclampsia with severe features, $88.9 \%$ cases had varying degrees of retinopathy.

Conclusions: As severity of preeclampsia increases, incidence of retinopathy also increases. Fundoscopy is a useful diagnostic aid and should be done to optimize fetomaternal outcome.
\end{abstract}

Keywords: Fundoscopy, Preeclampsia, Pregnancy, Retina

\section{INTRODUCTION}

Hypertensive disorders of pregnancy including preeclampsia complicates up to $10 \%$ of pregnancies all over the world and is a major cause of maternal and fetal morbidity and mortality. ${ }^{1}$ It is a syndrome that chiefly includes the development of new onset hypertension in the second half of pregnancy. Although it is often accompanied by new onset proteinuria, it can also be associated with many other signs and symptoms, like visual disturbances, headache, epigastric pain, etc. ${ }^{2}$

Hypertension in pregnancy is the second most common direct cause of maternal mortality worldwide and is amongst the leading causes of maternal deaths in developing countries like India. The incidence of this is approximately $10 \%$ leading to $17.2 \%$ of overall maternal mortality and $22 \%$ of fetal mortality. Thus, early detection and treatment are of paramount importance. ${ }^{3}$ 
The basic pathology in hypertensive disorder of pregnancy is believed to be endothelial dysfunction and generalized vasoconstriction which is multifactorial in origin. ${ }^{4}$ This results in widespread manifestation ranging from mild to severe depending on the degree of vasospasm and capillary leakage. This can affect multiple organ systems of the body leading to cardiovascular system dysfunction, hematological abnormalities, neurological or cerebral manifestations, renal and hepatic involvement etc. ${ }^{5}$ The placental involvement has potentially devastating consequences on the neonatal outcome. $^{6}$

Retinal changes occur in 30 to $100 \%$ patients with hypertensive disorders of pregnancy. ${ }^{7}$ The retina offers a unique opportunity to directly observe the pathological changes occurring in the vasculature. These vascular changes in the retina usually correlate with the severity of the systemic hypertension. ${ }^{8}$ Since fetal health depends on appropriate placental perfusion, observing the retina could indirectly be indicative of the placental perfusion and therefore fetal well-being. ${ }^{6}$ Severe disease requires urgent delivery to reverse the preeclamptic process and this needs to be carefully timed for optimum fetomaternal outcome. ${ }^{1,3}$ Fundoscopy is therefore a an important primary investigative procedure in the assessment of patients with this dreaded complication of pregnancy.

There are very few studies from Northern India which have studied the prevalence of fundal changes in hypertensive disorders of pregnancy and its association with severity of disease. ${ }^{9,10}$

This study was thus undertaken to evaluate the frequency and spectrum of retinal fundus changes in preeclampsiaeclampsia and to assess relationship of retinopathy with severity of hypertension in pregnancy.

\section{METHODS}

A cohort (observational) study. This study was a hospital based observational study conducted in tertiary care hospital attached to a medical college in a major town in Madhya Pradesh conducted over a period of a year. This is a multidisciplinary 1200 bedded hospital and a major referral center for neighboring areas and rural centers and subcenters. It has an average delivery rate of app 12000/annum.

\section{Sample size}

Based on the prevalence of retinopathy in hypertensive disorders of pregnancy as per previous study, using open epi sample size calculator for cohort study, the sample size was 76 at $95 \%$ confidence interval and power of study $90 \% .^{7}$

The hospital has an average delivery of 12,000 per annum. As this is a referral hospital, the number of cases of pre-clampsia seen is more than average prevalence of
$8 \%$. Thus, on the basis of case load in the department we were able to take 225 cases.

Inclusion and exclusion criteria

All antenatal patients presenting to the department of obstetrics and gynecology between 28 to 40 weeks of pregnancy fulfilling the diagnostic criteria of preeclampsia - eclampsia were included in the study.

\section{Inclusion criteria}

- Diagnosed antenatal patients of preeclampsiaeclampsia between 28-40 weeks pregnancy

- Willing to participate in the study.

\section{Exclusion criteria}

- Not willing to participate in the study

- Gestational hypertension

- Medical comorbidities like diabetes, epilepsy, collagen vascular disorder, cardiac disease, tuberculosis or any other medical disorder

- Presence of ocular media opacity precluding fundal examination.

\section{Study tool}

A proforma consisting of 7 sections was used. The first section was related to various demographic features like age, marital life etc. The second section was related to a detailed obstetric history including parity, gestational age, previous antenatal care etc.

A third section dealt with history of visual disturbances. Fourth section consisted general, systemic and obstetric examination including BP and fundus examination. The $5^{\text {th }}$ section was the lab investigations done at diagnosis of preeclampsia-eclampsia.

$6^{\text {th }}$ section comprised outcome in terms of mode of delivery, baby weight, Apgar score, admission to NICU, neonatal death and any maternal complications like coma, pulmonary oedema, oliguria, jaundice etc. and $7^{\text {th }}$ section included BP, fundus grade and proteinuria on $7^{\text {th }}$ day postpartum.

\section{Operational definitions}

Hypertensive retinopathy was graded according to KeithWagener classification

- Grade I: Mild generalized arterial attenuation

- Grade II: More severe grade 1 and focal arteriolar attenuation

- Grade III: Grade II + hemorrhages, hard exudates, cotton wool spots

- Grade IV: Grade III + optic disc swelling (papilledema). 
The severity of preeclampsia-eclampsia was classified into preeclampsia with or without severe features and eclampsia as per Acog criteria (2013).

Proteinuria was tested using dipstix method and was graded as $+=0.3 \mathrm{gm} / \mathrm{L},++=1 \mathrm{gm} / \mathrm{L}$, and $+++=3 \mathrm{gm} / \mathrm{L}$.

\section{Method of data collection}

After obtaining an informed consent, data were collected using the aforesaid proforma.

A detailed general physical, systemic and obstetric examination was done. The examination of the eye was done by an ophthalmologist. Bedside anterior segment, examination was done with simple torch light. Direct ophthalmoscopic fundus evaluation was done under plain $1 \%$ tropicamide eye drop. Hypertensive retinopathy changes seen in right or left or both eyes were taken as positive findings in that patient. The eye with the dominant findings was chosen. Hypertensive retinopathy was graded according to Keith- Wagener classification.

The patients were then divided into groups on the basis of retinal changes and compared in terms of demographic variables and severity of preeclampsia.

\section{Ethical consideration}

The study participants were explained about the objectives and purpose of the study. Informed written consent was taken from each participant prior to data collection. Privacy and confidentiality of each participant was assured. The study received ethical approval from the Institutional ethics committee.

\section{Statistical analysis}

The data was transferred and analysed using SPSS software version 22. Appropriate descriptive statistics like percentages and mean, standard deviation was used to describe the sociodemographic and risk factor variables. The difference in the prevalence of retinal changes among various groups of hypertensions was tested using Chi-square test and a $\mathrm{p}$ value of less than 0.05 was considered to be significant. ANOVA test was used to establish relationship between mean systolic and diastolic BP and grades of retinopathy.

\section{RESULTS}

The majority of cases $(48 \%)$ in the study were between 20-24 years age. $26.7 \%$ patients were between 16- 20 ears of age. The mean age of this study participants was $22.33 \pm 4.67$ years reflecting that most pregnancies were in the optimum childbearing age. Majority of cases $(61.8 \%)$ were nullipara while $38.2 \%$ were multipara. On analysing the booking status, it was found that $65.3 \%$ cases in the study were unbooked. The maximum number of cases had a gestational age between 33-36 weeks (44.4\%) with a mean gestational age of $34.84 \pm 2.96$ weeks (Table 1).

Table 1: Demographic characteristics of the study population.

\begin{tabular}{|c|c|c|}
\hline Variable & $\mathbf{N}$ & $\%$ \\
\hline \multicolumn{3}{|l|}{ Age group (years) } \\
\hline $16-20$ & 60 & 26.7 \\
\hline $21-25$ & 108 & 48.0 \\
\hline $26-30$ & 34 & 15.1 \\
\hline $31-35$ & 20 & 8.9 \\
\hline$>36$ & 3 & 1.3 \\
\hline Mean age \pm SD $($ years) $22.33 \pm 4.67$ & - & - \\
\hline \multicolumn{3}{|l|}{ Gravida } \\
\hline Primigravida & 139 & $61.80 \%$ \\
\hline Multigravida & 86 & $38.22 \%$ \\
\hline \multicolumn{3}{|l|}{ Booking status } \\
\hline Booked & 78 & $34.70 \%$ \\
\hline Unbooked & 147 & $65.30 \%$ \\
\hline \multicolumn{3}{|l|}{ Gestational age (weeks) } \\
\hline$<24$ weeks & 1 & $0.4 \%$ \\
\hline 25-28 weeks & 7 & $3.1 \%$ \\
\hline 29-32 weeks & 33 & $14.7 \%$ \\
\hline 33-36 weeks & 100 & $44.4 \%$ \\
\hline$>36$ weeks & 84 & $37.3 \%$ \\
\hline Mean GA \pm SD & - & - \\
\hline
\end{tabular}

Table 2: Clinical characteristics of study population.

\begin{tabular}{|c|c|c|c|}
\hline Variable & & $=225$ & $\%$ \\
\hline \multirow{4}{*}{$\begin{array}{l}\text { Severity of } \\
\text { HDP }\end{array}$} & $\begin{array}{l}\text { Preeclampsia without } \\
\text { severe features }\end{array}$ & 87 & 38.7 \\
\hline & $\begin{array}{l}\text { Preeclampsia with } \\
\text { severe features }\end{array}$ & 54 & 24 \\
\hline & Eclampsia & 78 & 34.7 \\
\hline & Chr Htn & 6 & 2.7 \\
\hline \multirow{2}{*}{$\begin{array}{l}\text { Retinal } \\
\text { changes }\end{array}$} & Present & 153 & 68.0 \\
\hline & Absent & 72 & 32.0 \\
\hline \multirow{4}{*}{$\begin{array}{l}\text { Fundal grade } \\
(\mathrm{KW}) \\
(\mathrm{n}=153)\end{array}$} & Grade 1 & 84 & 54.9 \\
\hline & Grade 2 & 50 & 32.7 \\
\hline & Grade 3 & 12 & 7.8 \\
\hline & Grade 4 & 7 & 4.6 \\
\hline $\begin{array}{l}\text { History of } \\
\text { visual } \\
\text { disturbance }\end{array}$ & Present & 72 & 32 \\
\hline \multirow{4}{*}{ Proteinuria } & $1+$ & 137 & 60.9 \\
\hline & $2+$ & 46 & 20.4 \\
\hline & $3+$ & 36 & 16.0 \\
\hline & $4+$ & 6 & 2.7 \\
\hline \multirow{3}{*}{$\begin{array}{l}\text { Lab } \\
\text { parameters }\end{array}$} & Deranged LFT & 31 & 13 \\
\hline & Deranged KFTS & 13 & 5.7 \\
\hline & Plts $<100,000 /$ cumm & 7 & 3.11 \\
\hline
\end{tabular}

Study showed that $38.7 \%$ patients were of preeclampsia without severe features while $34 \%$ were patients of eclampsia. Overall $68 \%$ patients had retinal changes on 
fundoscopic examination. Of those patients with retinal changes, most patients $(54.9 \%)$ had KW grade 1. Only $4.5 \%$ had grade 4 changes on fundoscopy. $32 \%$ of cases in this study had history of visual disturbances (Table 2).

Overall, the most common proteinuria observed was plus $1(60.8 \%)$. Only $2.7 \%$ had plus 4 proteinuria. $13 \%$ patients had deranged liver function test $(\mathrm{n}=31)$ and $5.1 \%$ cases had deranged kidney function tests $(n=13)$. Thrombocytopenia was present in $3.1 \%$ cases (Table 2 ).

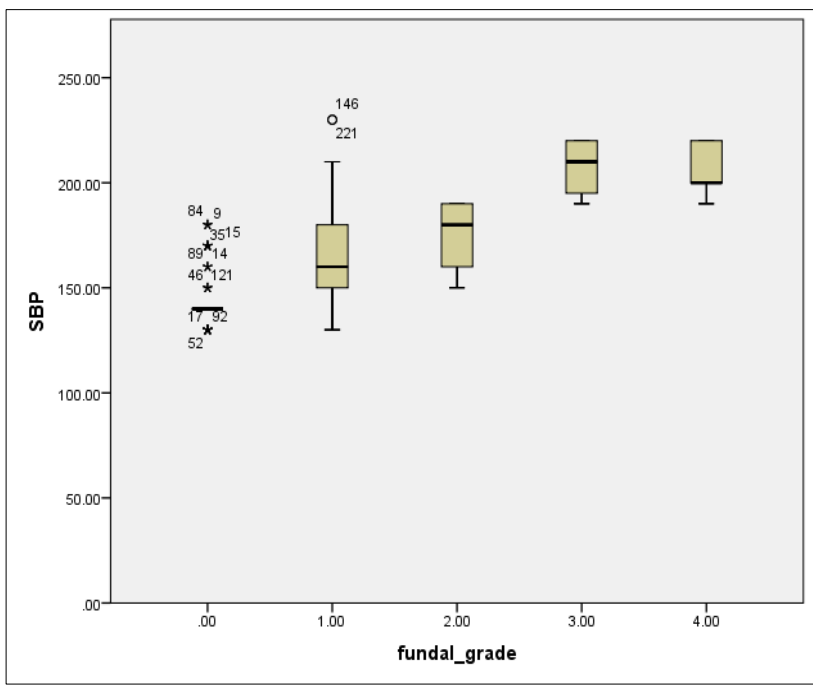

Figure 1: Comparison of mean systolic blood pressure with grades of retinopathy.

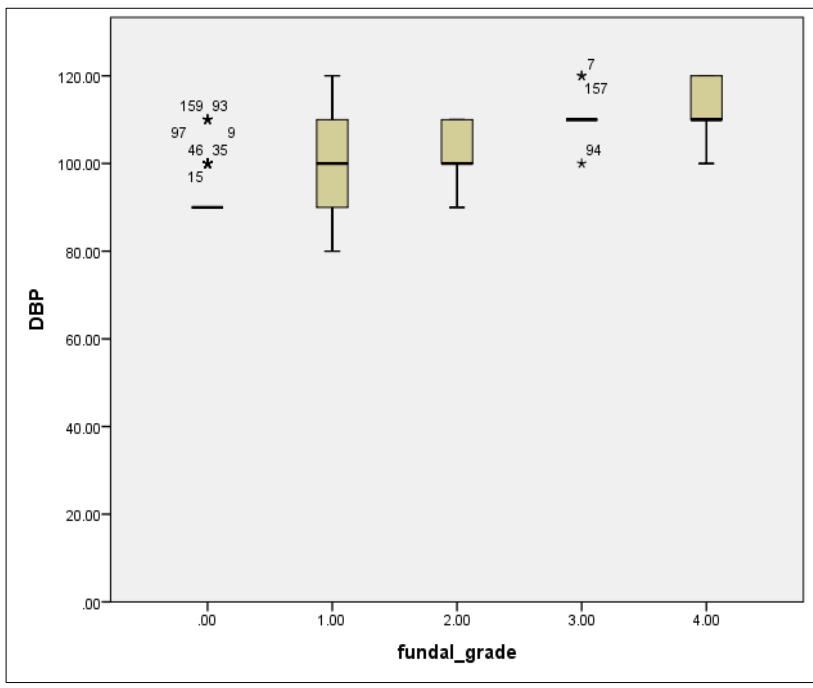

Figure 2: Comparison of diastolic blood pressure with grades of retinopathy.

Study showed the there was a significant rise in the mean systolic and diastolic blood pressure with increased grades of retinopathy. Mean BP in patients with no retinal change was $143.54 / 92.15 \mathrm{mmHg}( \pm \mathrm{SD} 4.84 / 8.56)$ and it was $207.14 / 112.86 \mathrm{mmHg}( \pm \mathrm{SD} 4.21 / 7.55)$ in patients with grade 4 changes. This difference in the mean systolic blood pressure and diastolic blood pressure was statistically significant (P-value 0.001). On applying Bonnferronis correction it was observed that the maximum difference was observed between grade 2 and 3 which gave a mean difference of -63.34 , with a $p$ value of $<0.0001$. This was statistically significant Figure 1 and 2.

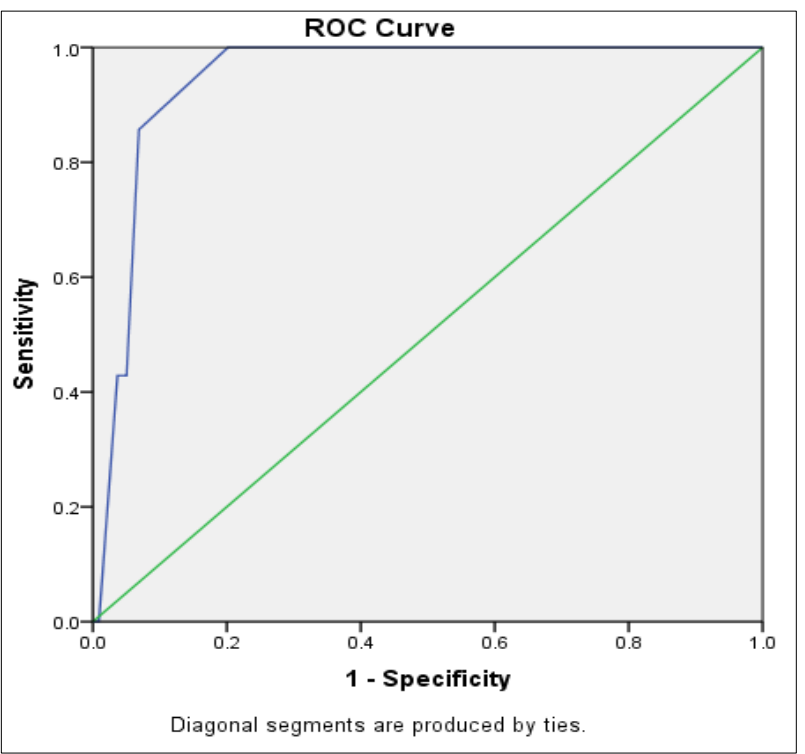

Figure 3: ROC curve predicting association between mean systolic bp and retinopathy.

On plotting an ROC curve, it was observed that there was significant association between the mean systolic blood pressure and retinopathy. It was seen that a blood pressure of $195 \mathrm{~mm} \mathrm{hg}$ had an $85.7 \%$ sensitivity and $93.1 \%$ specificity for predicting the presence of retinopathy. The area under curve (AUC) was a significant, 945 with a p-value of 0.001 with a confidence interval between 907 and 984. Thus, systolic BP was shown to be highly predictive of the presence of retinopathy (Figure 3).

It was observed that the mean age across all grades of retinopathy was similar ranging between 20.9 to 23.7 years. The mean gestational age for the group with grade 0 i.e. no fundal changes was $36.31 \pm 2.61$ weeks which was more than the mean gestational age as the grade progressed. It was $31.43 \pm 1.81$ weeks in grade 4 and this difference was statistically significant with a $p$ value $<0.001$. It was also observed that all cases of grade 3 and grade 4 were unbooked. $69.8 \%$ nullipara and $67.5 \%$ multipara had some changes on fundoscopy. There was no significant effect of parity on the occurrence of retinopathy. The most common grade observed among nullipara was grade 1 while it was grade 2 in multipara. $75 \%$ of grade 3 and $42.9 \%$ of grade 4 cases were seen among nullipara patients (Table 3 ).

A total $32 \%$ of cases had history of visual disturbances. Of these 32 cases, $93 \%$ had varying grades of retinopathy. The most common complaint was blurring of 
vision $(58.3 \%) .98 \%$ patients with history of blurring of vision also had changes on fundoscopy. Most patients with blurring of vision and dimness of vision had grade 1 (59.5\% and $58.3 \%$ respectively). Surprisingly, none of the patients with grade 4 retinopathy gave history of visual disturbances. This may be related to severity of the disease occurring suddenly e.g. eclampsia which did not give the patients time to realize that they had visual symptoms (Table 3 ).

Table 3: Comparison of retinopathy with basic characteristics of the study population.

\begin{tabular}{|c|c|c|c|c|c|c|c|c|}
\hline \multicolumn{2}{|l|}{ Variable } & $\begin{array}{l}\text { Grade } 0 \\
\mathbf{N}=72(\%)\end{array}$ & $\begin{array}{l}\text { Grade } 1 \\
N=84(\%)\end{array}$ & $\begin{array}{l}\text { Grade } 2 \\
\mathbf{N}=\mathbf{5 0}(\%)\end{array}$ & $\begin{array}{l}\text { Grade } 3 \\
N=12(\%)\end{array}$ & $\begin{array}{l}\text { Grade } 4 \\
N=7(\%)\end{array}$ & $\begin{array}{l}\text { Total } \\
\mathbf{N}=\mathbf{2 2 5}(\%)\end{array}$ & $\begin{array}{l}P \text { - } \\
\text { value }\end{array}$ \\
\hline \multicolumn{2}{|c|}{ Mean Age \pm SD (years) } & $22.69 \pm 4.90$ & $21.26 \pm 3.56$ & $23.76 \pm 5.63$ & $20.92 \pm 3.42$ & $23.57 \pm 5.77$ & $22.33 \pm 4.67$ & 0.024 \\
\hline \multicolumn{2}{|c|}{ Mean GA \pm SD (weeks) } & $36.31 \pm 2.61$ & $34.62 \pm 2.94$ & $34.08 \pm 2.81$ & $32.83 \pm 1.99$ & $31.43 \pm 1.81$ & $34.84 \pm 2.96$ & $.001^{*}$ \\
\hline \multirow{2}{*}{$\begin{array}{l}\text { Booking } \\
\text { status }\end{array}$} & Booked & $31(43.1)$ & $29(34.5)$ & $18(36.0)$ & $0(0.0)$ & $0(0.0)$ & $78(34.7)$ & \multirow{2}{*}{$0.015^{*}$} \\
\hline & Unbooked & $41(56.9)$ & $55(65.5)$ & $32(64.0)$ & $12(100.0)$ & $7(100.0)$ & $147(65.3)$ & \\
\hline \multirow{2}{*}{ Parity } & Nullipara & $42(58.3)$ & $61(72.6)$ & $24(48.0)$ & $9(75.0)$ & $3(42.9)$ & $139(61.8)$ & \multirow{2}{*}{$0.032^{*}$} \\
\hline & Multipara & $30(41.7)$ & $23(27.4)$ & $26(52.0)$ & $3(25.0)$ & $4(57.1)$ & $86(38.2)$ & \\
\hline \multirow{4}{*}{$\begin{array}{l}\mathrm{H} / \mathrm{O} \\
\text { visual } \\
\text { symptoms }\end{array}$} & $\begin{array}{l}\text { Blurring of } \\
\text { vision }\end{array}$ & $2(2.8)$ & $25(29.8)$ & $8(16.0)$ & $7(58.3)$ & $0(0.0)$ & 42 (18.7) & \multirow{4}{*}{$<0.001$} \\
\hline & $\begin{array}{l}\text { Dimness of } \\
\text { vision }\end{array}$ & $2(2.8)$ & $14(16.7)$ & $5(10.0)$ & $3(25.0)$ & $0(0.0)$ & $24(10.7)$ & \\
\hline & loss of $v / n$ & $1(1.4)$ & $5(6.0)$ & $0(0.0)$ & $0(0.0)$ & $0(0.0)$ & $6(2.7)$ & \\
\hline & No history & $67(93.1)$ & $40(47.6)$ & $37(74.0)$ & $2(16.7)$ & $7(100.0)$ & $153(68.0)$ & \\
\hline
\end{tabular}

p-value $<0.05$ significant.

Table 4: Comparison of severity of preeclampsia and lab parameters with retinopathy.

\begin{tabular}{|c|c|c|c|c|c|c|c|c|}
\hline Variable & & $\begin{array}{l}\text { Grade } 0 \\
\mathbf{N}=72(\%)\end{array}$ & $\begin{array}{l}\text { Grade } 1 \\
\mathbf{N}=\mathbf{8 4}(\%)\end{array}$ & $\begin{array}{l}\text { Grade } 2 \\
\mathbf{N}=\mathbf{5 0}(\%)\end{array}$ & $\begin{array}{l}\text { Grade } 3 \\
N=12(\%)\end{array}$ & $\begin{array}{l}\text { Grade } 4 \\
N=7(\%)\end{array}$ & $\begin{array}{l}\text { Total } \\
\mathbf{N}=225(\%)\end{array}$ & $\begin{array}{l}P \text { - } \\
\text { value }\end{array}$ \\
\hline \multirow{4}{*}{$\begin{array}{l}\text { Severity of } \\
\text { preclampsia }\end{array}$} & $\begin{array}{l}\text { PE without } \\
\text { severe features }\end{array}$ & $57(79.2)$ & $27(32.1)$ & $3(6.0)$ & $0(0.0)$ & $0(0.0)$ & $87(38.7)$ & \multirow{4}{*}{$\begin{array}{l}< \\
0.0001^{*}\end{array}$} \\
\hline & $\begin{array}{l}\text { PE with severe } \\
\text { features }\end{array}$ & $6(8.3)$ & $27(32.1)$ & $17(34.0)$ & $3(25.0)$ & $1(14.3)$ & $54(24.0)$ & \\
\hline & Eclampsia & $9(12.5)$ & $30(35.7)$ & $24(48)$ & $9(75)$ & $3(42.9)$ & $64(28.4)$ & \\
\hline & $\begin{array}{l}\text { Chronic } \\
\text { hypertension }\end{array}$ & $0(0.0)$ & $0(0.0)$ & $6(12.0)$ & $0(0.0)$ & $0(0.0)$ & $6(2.7)$ & \\
\hline \multirow{4}{*}{ Protienuria } & +1 & $63(87.5)$ & $41(48.8)$ & $29(58.0)$ & $3(25.0)$ & $1(14.3)$ & $137(60.9)$ & \multirow{4}{*}{$\begin{array}{l}< \\
0.0001^{*}\end{array}$} \\
\hline & +2 & $9(12.5)$ & $25(29.8)$ & $12(24.0)$ & $0(0.0)$ & $0(0.0)$ & $46(20.4)$ & \\
\hline & +3 & $0(0.0)$ & $18(21.4)$ & $9(18.0)$ & $6(50.0)$ & $3(42.9)$ & $36(16.0)$ & \\
\hline & +4 & $0(0.0)$ & $0(0.0)$ & $0(0.0)$ & $3(25.0)$ & $3(42.9)$ & $6(2.7)$ & \\
\hline \multirow{2}{*}{$\begin{array}{l}\text { Liver } \\
\text { function } \\
\text { tests }\end{array}$} & $\begin{array}{l}\text { Deranged } \\
\mathrm{N}=31\end{array}$ & $8(11.1)$ & 10 (11.9) & $7(12.0)$ & $3(25.0)$ & $3(42.9)$ & $31(13.3)$ & \multirow[t]{2}{*}{0.139} \\
\hline & Normal & $64(88.9)$ & $74(88.1)$ & $43(86.0)$ & $9(75.0)$ & $4(57.1)$ & $194(86.2)$ & \\
\hline \multirow{2}{*}{$\begin{array}{l}\text { Kidney } \\
\text { function tests }\end{array}$} & Deranged & $0(0.0)$ & $3(3.6)$ & $7(14.0)$ & $0(0.0)$ & $3(14.3)$ & $13(4.9)$ & \multirow{2}{*}{$\begin{array}{l}< \\
0.0001^{*}\end{array}$} \\
\hline & Normal & $72(100.0)$ & $81(96.4)$ & $43(86.0)$ & $12(100.0)$ & $4(57.1)$ & $212(94.2)$ & \\
\hline \multirow[t]{2}{*}{ Platelets } & $\begin{array}{l}<100,000 / \mathrm{cu} \\
\mathrm{mm}\end{array}$ & $13(18.1)$ & $6(7.1)$ & $11(22.0)$ & $4(33.3)$ & $1(14.3)$ & $35(15.6)$ & \multirow[t]{2}{*}{0.053} \\
\hline & $>100,000 /$ cumm & $59(81.9)$ & $78(92.9)$ & $39(78.0)$ & $8(66.7)$ & $6(85.7)$ & $190(84.4)$ & \\
\hline
\end{tabular}

*p-value $<0.05$ significant.

It was observed that of the patients of preeclampsia without severe features (i.e. mild cases), $65.5 \%$ had no retinopathy. Of the changes observed, grade 1 was most common $(31 \%)$. None of the patients had grade 3 or 4 changes. In the patients of preeclampsia with severe features, $88.9 \%$ cases had varying degrees of retinopathy, the most common grade still being grade $1(50 \%)$. In the group of eclampsia also, $88.5 \%$ had some degree of retinopathy. Thus, as severity of disease increased, incidence of retinopathy also increased (Table 4). 
In this study, $46 \%$ of patients with plus 1 proteinuria had no retinopathy and $29 \%$ had grade 1 only. Compared to this, in patients with proteinuria of 4 plus, $50 \%$ had grade 3 and $50 \%$ had grade 4 changes showing a significant correlation between the degree of proteinuria and retinopathy (Table 4).

Of the patients with deranged liver function test $(\mathrm{n}=31)$, $25.8 \%$ had no retinopathy, $32.3 \%$ had grade 1 changes. Only $9.7 \%$ had grade 3 and 4 changes. Of the patients with deranged kidney function tests $(n=13)$, all patients $(100 \%)$ had some degree of retinopathy. The most common change was grade $2(53.8 \%)$ and $23.1 \%$ had grade 4 change. On analysing the cases of thrombocytopenia in the study, $37.1 \%$ had no retinopathy. The most common retinopathy was grade 2 changes (Table 4).

On looking at the more severe grades of retinopathy in table 4 , it can be observed that $25 \%$ of grade 3 retinopathy patients were preeclampsia with severe features and $75 \%$ were of eclampsia. $85.7 \%$ of grade 4 retinopathy cases were in the group of eclampsia. Also $50 \%$ cases with grade 3 retinopathy had proteinuria 3 plus and $25 \%$ had 4 plus proteinuria. Overall $85.8 \%$ patients with grade 4 retinopathy had high grade of proteinuria (>2 plus). $42.9 \%$ patients with grade 4 retinopathy had deranged liver function tests and kidney function tests. $33.4 \%$ patients with grade 3 changes had platelets less than 1 lakh/cumm (Table 4).

\section{DISCUSSION}

The mean age in this study was $22.33 \pm 4.67$ years. This was similar to other studies which showed an average age that varied from 23 years to 29 years. ${ }^{8-10}$ Unlike Varija et al, study did not show more no of patients in a younger age group (16-20 years). ${ }^{11}$ Shah AP et al, also showed no changes on fundoscopy in patients younger than 19 years. $^{12}$

Overall $65.5 \%$ of patients were unbooked and $72.1 \%$ of these patients had some degree of retinopathy. Thus, the severity of disease and retinopathy was more in the unbooked population. This is in consonance with other studies that suggest that unbooked women tend to have more severe complications of pregnancy. ${ }^{13}$ This can be explained by the fact that the hospital serves as a referral centre to a large rural population where booking is inadequate. A large no of unbooked patients came to the hospital in the last minute with various complications like seizures etc.

Preeclampsia occurs more commonly among nulliparous women and study also demonstrated that $61.8 \%$ women in the study were nulliparous. ${ }^{14}$ There was, however, no significant difference in the occurrence of retinopathy between nulliparous and multiparous women. Similar findings were reported by Reddy et al. ${ }^{15}$ While Bharati et al reported a significant correlation of retinopathy with primigravida, Shah AP et al reported more retinal changes among multipara women though not statistically significant. ${ }^{10,12}$

The severity of preeclampsia correlated with the occurrence of retinal changes. $65.5 \%$ of patients with preeclampsia without severe features showed no changes on fundoscopy while $88.9 \%$ cases of severe preeclampsia and eclampsia had positive findings. The presence of systolic BP of $195 \mathrm{~mm}$ hg had $85.7 \%$ sensitivity and $93.1 \%$ specificity for predicting the presence of retinopathy. The area under curve (AUC) is a significant .945 with a P-value of .001 with a confidence interval between 907 and 984. Thus, systolic BP was highly predictive of the presence of retinopathy. Similar results have been reported by Tadin et al, who reported that the degree of retinopathy was directly proportional to severity of preeclampsia. ${ }^{8}$ This was also supported by Varija et al, Jaffe and Savitha. ${ }^{9,11,16}$ All cases of severe retinopathy i.e. grade 3 or grade 4 was observed in patients with either severe pre-eclampsia or eclampsia. Similar results have been reported by Shah AP. ${ }^{12}$

In this study $68 \%$ patients had retinopathy which was similar to studies by Hallum way back in $1936 .^{7}$ Recent studies also quote the prevalence as $71 \%$ by Neha et al and $42.8 \%$ by Varija etal. ${ }^{11,17}$ Other studies show a varied range between $38.46 \%$ to $60 \%{ }^{8,15,18,19}$ Bharati reported a prevalence of $23 \%$ and concluded that hypertensive retinopathy of pregnancy is largely underdiagnosed. ${ }^{10}$

Of all the changes, grade 1 was the most common $(54.9 \%)$ this was in consonance with other studies. ${ }^{10,11,15,19}$

While Sunness and Diekmann WJ reported the presence of visual symptoms in $30-50 \%$ in patients with eclampsia and $20-25 \%$ patients with preeclampsia, Neha et al reported an incidence of $70 \%$ visual symptoms in eclampsia and $15 \%$ of preeclampsia. ${ }^{17,20,21}$ Study also had $32 \%$ incidence of visual symptoms. $93 \%$ of those patients had varying grades of retinopathy. Thus, patients with visual history were more likely to have retinal changes. Compared to this only $56 \%$ patients with no history of visual symptoms had retinal changes. It was surprising to note that all cases with grade 4 changes had no prior history of visual complaints. It may indicate that the episodes were sudden e.g. cases of sudden onset eclampsia where patients did not have time to realize they had visual changes. It may also be that the patients had other complaints like headache which was more severe and therefore they did not realize the presence of their visual complaints.

The mean BP in patients with no retinal change was $143.54 / 92.15 \mathrm{mmHg}( \pm \mathrm{SD} \quad 4.84 / 8.56)$ and it was 207.14/112.86 mmHg ( \pm SD 4.21/7.55) in patients with grade 4 changes. Thus, there was a significant rise in the mean systolic and diastolic blood pressure with increasing grade of retinal change (p-value 0.001). Neha 
etal reported a significantly higher systolic and diastolic $\mathrm{BP}$ in those patients with retinopathy. ${ }^{17} \mathrm{~A}$ significant association between blood pressure readings and retinopathy has been demonstrated in other studies as well. $^{6,8,12,15}$

There was a significant correlation between the degree of protienuria and retinopathy. Similarly Neha et al reported a significant association of severity of retinopathy with protienuria which was also in consonance with Reddy, Tadin, Shah and Karki et al. 6,8,12,15,17 Study also showed that all patients with deranged kidney function tests had some degree of retinopathy. On analysing the cases of thrombocytopenia, $62.9 \%$ had retinopathy. Kishore et al have reported that biochemical markers like blood urea and serum creatinine deteriorate as retinopathy increases. $^{22}$

Limitations of this study were that review of retinal changes at 6 weeks should be done. A multicentric study with a larger sample size is likely to provide better results by removing the effect of confounding variables.

\section{CONCLUSION}

Retinal changes occur in 30 to $100 \%$ patients with hypertensive disorders of pregnancy. The retina offers a unique opportunity to directly observe the pathological changes occurring in the vasculature. As these vascular changes in the retina usually correlate with the severity of the systemic hypertension, the eyes can truly be considered a mirror to the otherwise elusive vascular changes occurring elsewhere in the body. It thus stands to reason that observing the retinal changes holds the ability to prognosticate and also determine the severity of the disease. Fundoscopy is an essential investigation that needs to be done in all cases of hypertensive disorders of pregnancy.

Funding: No funding sources

Conflict of interest: None declared

Ethical approval: The study was approved by the Institutional Ethics Committee

\section{REFERENCES}

1. World Health Organization. World Health Statistics 2015. Available at: http://www.who.int/gho/publications/world_health_s tatistics/2015/en/. Accessed on $5^{\text {th }}$ September 2017.

2. Roberts JM, August PA, Bakris G, Barton JR, Bernstein IM, Druzin $M$ et al. Hypertension in pregnancy. Report of the American College of Obstetricians and Gynecologists' Task Force on Hypertension in Pregnancy. Obstet Gynecol. 2013;122(5):1122-31.

3. Duley L. The global impact of pre-eclampsia and eclampsia. Semin Perinatol. 2009;33(3):130-7.

4. Roberts JM, Taylor RN, Musci TJ, Rodgers GM, Hubel CA, McLaughlin MK. Preeclampsia: An endothelial cell disorder. Am J Obstet Gynecol. 1989;161:1200-4.

5. Richard RO. Pregnancy induced hypertension (preeclampsia-ecclampsia) In: Schachat AP, Murphy RB, eds. Retina. $2^{\text {nd }}$ ed. St Louis: Mosby. 1994:140512.

6. Karki P, Malla KP, Das H, Uprety DK. Association between pregnancy induced hypertensive fundus changes and fetal outcome. Nepal J Ophthalmol. 2010;2(1):26-30.

7. Hallum AV. Eye changes in hypertensive toxemia of pregnancy: a study of 300 cases. JAMA 1936;106(9):1649-51.

8. Tadin I, Bojic L, Mimica M, Karelovic D, Dogas Z. Hypertensive retinopathy and preeclampsia. Coll Antropol. 2001;25:77-81.

9. Savitha HC, Kumar CS, Sowmya MS. A retrospective study of association of fundal changes and foetal outcome in preeclampsia and eclampsia. MedPulse - Int Med J. 2015;2(8):433-6.

10. Bharathi NR, Raju NS, Prasad PK, Raju RN, Premalatha, Mayee $\mathrm{K}$ et al. Fundus changes in pregnancy induced hypertension: A clinical study. J Med Dent Sci. 2015;4(9):1552-62.

11. Varija T, Vanaja D, Sindhura, Raghavenda B. A study of prevalence and association of fundus changes in pregnancy induced hypertension. Int $\mathbf{J}$ Reprod Contracept Obstet Gynecol. 2016;5:1375-9.

12. Shah AP, Lune AA, Magdum RM, Deshpande H, Shah AP, Bhavsar D. Retinal changes in pregnancy induced hypertension. Med J DY Patil Univ 2015;8:304-7.

13. Owolabi AT, Fatusi AO, Kuti O, Adeyemi A, Faturoti SO, Obiajuwa PO. Maternal complications and perinatal outcomes in booked and unbooked Nigerian mothers. Singapore Med J. 2007;49:526-31.

14. Catov JM, Ness RB, Kip KE, Olsen J. Risk of early or severe preeclampsia related to pre-existing conditions, Int J Epidemiol. 2007;36(2):412-9.

15. Reddy SC, Naliah S, Rani S. Fundus changes in pregnancy induced hypertension. Int J Ophthalmol. 2012;5(6);694-7.

16. Jaffe $G$, Schatz H. ocular manifestations of preeclampsia. Am J Ophthalmol. 1987;103(3 Pt1):309-15.

17. Pathak N, Singh J, Meena AK, Gupta T, Jain M. One year cross-sectional study of fundal changes in patients with pregnancy - induced hypertension. Int $\mathbf{J}$ Med Res. 2017;3(2):68-73.

18. Das KA, Jaisal P. Fundus changes in pregnancy induced hypertension. Int $\mathrm{J}$ Med Res Prof. 2016;2(2):47-50.

19. Kamath RK, Nayak SR. Preeclampsia/eclampsia and retinal micro vascular characteristics affecting maternal and foetal outcome: a prospective study amongst south Indian pregnant women. IJIRD. 2013;2(11):444-8.

20. Sunness JS. The pregnant woman's eye. Surv Ophthalmol. 1988;32(4):219-38. 
21. Dieckmann WJ. The toxemias of pregnancy, $2^{\text {nd }}$ ed., CV Mosby, St. Louis; 1952:496-506.

22. Kishore N, Tandon S. Significance of biochemical and ophthalmoscopic changes in toxemia of pregnancy. J Obstet Gynec India. 1965;15(6):551-9.
Cite this article as: Sharma JC, Choudhary B, Maru $\mathrm{L}$, Mathur P. The retina in hypertensive disorders of pregnancy: a study of the prevalence and association with severity of disease in a tertiary referral centre in India. Int J Reprod Contracept Obstet Gynecol 2020;9:375-82. 